\title{
WIKILEAKS, ASSANGE Y EL FUTURO DEL ASILO DIPLOMÁTICO
}

\author{
Ricardo ARREDONDO *
}

SUMARIO: 1. INTRODUCCIÓN.-2. EL DERECHO DE ASILO.-2.1. Terminología.-2.2. El marco jurídico vigente.-2.2.1. El Derecho internacional general.-2.2.2. El asilo en América Latina.-2.3. La práctica estatal.-3. EL CASO ASSANGE.-3.1. Antecedentes.-3.2. Los fundamentos de la concesión de asilo y sus respuestas.-3.3. La solicitud de opinión consultiva a la Corte Interamericana de Derechos Humanos.-4. EL FUTURO DEL ASILO DIPLOMÁTICO.

\section{INTRODUCCIÓN}

1. El asilo diplomático es consecuencia de una práctica nacida en América Latina, a partir de la protección ejercida por el Estado acreditante respecto de una persona requerida por el Estado receptor, donde la inviolabilidad del local diplomático es la que impide su detención y, teóricamente, facilita la obtención del salvoconducto necesario para que el individuo pueda salir del país. Este no es el caso de Julian Assange, fundador de WikiLeaks y una de las personas más buscadas en Google, que se encuentra "alojado» en el departamento 3B, 3 Hans Crescent, Knightsbridge, London SW1X 0LS (la sede de la Embajada de Ecuador ante el Reino Unido). El objetivo de este artículo es considerar el marco jurídico y la práctica del asilo diplomático, para después referirnos en concreto a la situación de Julian Assange, la reciente solicitud de una opinión consultiva de Ecuador a la Corte Interamericana de Derechos Humanos y concluir con algunas reflexiones acerca del futuro del asilo diplomático.

\footnotetext{
* Profesor de Derecho internacional público en la Universidad de Buenos Aires (ricardoarredondo@derecho.uba.ar).
} 


\section{EL DERECHO DE ASILO}

\subsection{Terminología}

2. El Institut de Droit International ha definido el término asilo como la protección que un Estado concede dentro de su territorio u otro lugar bajo el control de alguno de sus órganos a una persona que ha venido a solicitarla ${ }^{1}$. Esta definición incluye la distinción fundamental entre asilo territorial y asilo diplomático. Ambas figuras procuran un mismo fin, que es «la protección que dispensa un Estado a una persona no nacional que es objeto de persecución en virtud de motivos políticos o ideológicos por las autoridades de otro Estado ${ }^{2}$. El asilo territorial se refiere a la potestad de todo Estado, en el ejercicio de su soberanía, de admitir dentro de su territorio a las personas que juzgue conveniente, sin que por ello ningún otro Estado pueda hacer reclamo alguno y sin importar el modo en que la persona haya ingresado en su territorio. Consecuentemente, no existe una obligación de entregar a otro Estado o a expulsar de su territorio a personas perseguidas por motivos o delitos políticos y no procede la extradición. El asilo territorial, en ocasiones utilizado como sinónimo de refugio, no es objeto de análisis en este trabajo ${ }^{3}$.

3. En el informe del secretario general de las Naciones Unidas sobre la cuestión del asilo diplomático, "se entiende asilo diplomático en sentido amplio el asilo concedido por un Estado fuera de su territorio, especialmente en sus misiones diplomáticas (asilo diplomático en sentido estricto), en sus consulados, a bordo de sus naves situadas en las aguas territoriales de otro Estado (asilo naval), así como a bordo de sus aeronaves y sus instalaciones militares o para-militares situadas en territorio extranjero ${ }^{4}$. El informe destaca asimismo que "la terminología en toda esta materia carece de uniformidad. En efecto, las expresiones "asilo interno", "asilo externo" y "asilo político" designan para algunos el asilo diplomático y para otros el asilo territorial $»^{5}$. El Estado en cuyo territorio se solicita el asilo diplomático se conoce como Estado territorial o receptor, si se utiliza la terminología de la Convención de Viena sobre Relaciones Diplomáticas de 1961 (CVRD) ${ }^{6}$. Al Estado que concede el asilo se lo designa como Estado asilante o acreditante.

4. El derecho de asilo se dirige al Estado y no al individuo, en virtud del ejercicio de la propia soberanía y con la única reserva de límites eventuales

${ }^{1}$ Institut de Droit International, Reunión de Bath, 11 de septiembre de 1950, Annuaire, 1950, art. 1.

2 Pastor Ridruejo, A., Curso de Derecho Internacional Público y Organizaciones Internacionales,

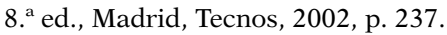

3 Sobre esta cuestión, entre otros puede verse Gros EsPIELL, H., «El derecho internacional americano sobre asilo territorial y extradición en sus relaciones con la Convención de 1951 y el Protocolo de 1967 sobre el Estatuto de los Refugiados», en Asilo y protección internacional de los refugiados en América Latina, México, UNAM, 1982.

4 Asamblea General de las Naciones Unidas (AGNU), Informe del Secretario General. Cuestión del asilo diplomático, 22 de septiembre de 1975, Doc. A/10139 (parte II), p. 5.

${ }_{5}$ Ibid.

${ }^{6}$ La CVRD fue firmada en Viena el 18 de abril de 1961 y entró en vigor el 24 de abril de 1964. 
que derivan de convenciones de las que el Estado forma parte ${ }^{7}$. Sin embargo, hay quienes entienden que el derecho de asilo se inscribe dentro del esquema de protección de los derechos humanos y que, por ende, no es solo una prerrogativa del Estado, sino un derecho humano, "como una garantía individual plenamente operativa que puede y debe ser complementado con otras formas de protección ${ }^{8}$.

\subsection{El marco jurídico vigente}

5. El asilo diplomático, institución existente en la antigüedad y ligada a la figura de la inviolabilidad de la misión diplomática ${ }^{9}$, fue paulatinamente cayendo en desuetudo ${ }^{10}$ al irse abandonando la ficción de la extraterritorialidad de la misión. Sin embargo, en el marco interamericano, el derecho de asilo cobró forma a través de diversos instrumentos que fueron suscribiendo los países de la región desde finales del siglo XIX. Por ello, consideramos conveniente desdoblar el análisis del marco jurídico, analizando primeramente el Derecho internacional general, para luego repasar el latinoamericano.

\subsubsection{El Derecho internacional general}

6. A excepción de los acuerdos existentes en el plano latinoamericano, que serán analizados en el numeral siguiente, ningún tratado o convenio internacional regula directamente el derecho de asilo diplomático como obligación internacional de los Estados ${ }^{11}$, aunque, veremos a continuación, ciertos regímenes internacionales, como la Convención de Viena sobre Relaciones Diplomáticas (CVRD) o el Derecho internacional de los derechos humanos, contienen normas que se relacionan con esta institución.

7. El derecho de asilo fue incluido en la Declaración Universal de los Derechos Humanos ${ }^{12}$ (DUDH) y la Declaración Americana de Derechos y De-

\footnotetext{
7 Imaz, C., "El asilo diplomático en la política exterior de México», 40-41 Revista Mexicana de Política Exterior, 1993, p. 54.

8 Mondelli, J. I., El asilo como derecho humano en el derecho argentino, Buenos Aires, junio de 2008, disponible en http://www.acnur.org/fileadmin/Documentos/BDL/2014/6418.pdf? view=1 (consultada el 19 de abril de 2017).

9 Véase ArRedondo, R., Derecho Diplomático y Consular, Buenos Aires, Abeledo-Perrot, 2016 , p. 126.

10 De Visscher, C., Théories et Réalités en droit international public, 3. a ed., París, Pedone, 1960, pp. 233-234.

11 Behrens, P., «The Law of Diplomatic Asylum. A Contextual Approach», Michigan Journal of International Law, vol. 35, 2014, pp. 319-367, pp. 328-329.

${ }_{12}$ Véase el art. 14. Cuando se redactó la DUDH, Bolivia y Uruguay propusieron una enmienda a la disposición relativa al derecho de asilo (el art. 14 mencionado) en el sentido de que el derecho se extendería al asilo en embajadas y legaciones. Las enmiendas, sin embargo, no lograron consenso y debieron ser retiradas. Véanse en los trabajos preparatorios de la Declaración los documentos A/C.3/227, A/C.3/268 y A/C.3/SR.122.
} 
beres del Hombre (DADDH) ${ }^{13}$, ambas de 1948. Estas convenciones recogen el asilo territorial y no así el diplomático y lo restringen a los delitos políticos. La Convención Americana de Derechos Humanos (CADH) ${ }^{14}$ se refiere únicamente al derecho de asilo territorial, en su art. 22.7 ${ }^{15}$. Sin embargo, estas disposiciones no fueron recogidas en el sistema de Naciones Unidas, ni en el Pacto de Derechos Civiles y Políticos ni en el de Derechos Económicos, Sociales y Culturales, ambos de 1966, como así tampoco en el régimen europeo, bajo la Convención Europea de Derechos Humanos (CEDH) (1950).

8. Cuando se encomendó a la Comisión de Derecho Internacional de las Naciones Unidas (CDI) la formulación de las normas sobre privilegios e inmunidades diplomáticas, una de las cuestiones controvertidas fue la posibilidad de formular una norma sobre el asilo diplomático. Finalmente, se acordó que la cuestión del asilo diplomático debía dejarse de lado y el tema no fue expresamente considerado en el contexto de la labor de la CDI ni en la Conferencia subsiguiente que negoció la Convención de Viena sobre Relaciones Diplomáticas.

9. La disposición establecida en el art. 41.3 CVRD establece que: «Los locales de la misión no deben ser utilizados de manera incompatible con las funciones de la misión tal como están enunciadas en la presente Convención, en otras normas del Derecho internacional general o en los acuerdos particulares que estén en vigor entre el Estado acreditante y el Estado receptor». Si existen acuerdos entre el Estado acreditante y el receptor, no habría inconveniente para el otorgamiento de asilo. Sin embargo, en ausencia de acuerdos especiales, la cuestión del asilo dependerá, por una parte, del deber de no interferir con los asuntos internos del Estado receptor y de no utilizar los locales diplomáticos y consulares de manera incompatible con las funciones diplomáticas establecidas; y, por otra parte, del principio de inviolabilidad de los locales diplomáticos.

10. Aunque el art. 41.3 CVDR establece la prohibición de abuso de los locales diplomáticos, no prevé que la inviolabilidad se pierda como consecuencia de dicho abuso. En respuesta al asilo concedido a Assange, los ministros de Relaciones Exteriores de la Organización de Estados Americanos (OEA) aprobaron una resolución en la que rechazaron "cualquier intento que ponga en riesgo la inviolabilidad de los locales de las misiones diplomáticas y reiterar la obligación que tienen todos los Estados de no invocar normas de Derecho interno para justificar el incumplimiento de sus obligaciones inter-

13 Véase el art. XXVII.

14 La Convención Americana sobre Derechos Humanos (también llamada Pacto de San José de Costa Rica) firmada en San José de Costa Rica el 22 de noviembre de 1969 y entró en vigor el 18 de julio de 1978. Disponible en http://tratados.mrecic.gov.ar/tratado_archivo.php?tratados_ $i d=3053 \&$ tipo $=3 \& i d=490 \&$ caso $=p d f$ (consultada el 13 de abril de 2017).

15 Ricart, L. T., «Artículo 22. Derecho de Circulación y de Residencia», en Alonso Regueira, E. (coord.), La Convención Americana de Derechos Humanos y su proyección en el Derecho Argentino, Buenos Aires, La Ley, 2013, p. 383. 
nacionales, y en este contexto manifestar su solidaridad y respaldo al Gobierno de la República del Ecuador» ${ }^{16}$.

11. Si bien es cierto que el derecho de asilo y la inviolabilidad de los locales de la misión son instituciones diferentes, existen puntos concretos de conexión entre ambos institutos. Aunque en la CVRD no existan disposiciones que regulen expresamente el asilo diplomático, existen otras que son relevantes en esta materia. En primer lugar, el párr. 1 del art. 41 requiere que los diplomáticos y todas aquellas personas que gocen de privilegios e inmunidades respeten las leyes y reglamentos internos del Estado receptor. En segundo lugar, la CVRD busca asegurar la inviolabilidad de los locales, por un lado, mediante la prohibición impuesta al Estado receptor de penetrar en ellos sin el consentimiento del jefe de misión (art. 22.1), y por otro, por medio de una obligación especial de protección debiendo «adoptar todas las medidas adecuadas» para protegerlos de toda intrusión o daño (art. 22.2). Dado que el art. 22 CVRD no contiene excepciones al principio de inviolabilidad, ello significa que, aún si el asilo se concede sin permiso o derecho del Estado receptor, la entrega de un asilado no puede ser ejecutada mediante un ingreso forzado a una representación diplomática u otros locales de la misión, como la residencia del jefe de la misión o los medios de transporte de este, que también gozan de inviolabilidad.

12. Ronning afirma que la única generalización que parece aceptable es que la práctica de los Estados en este sentido no se basa en ningún derecho de asilo generalmente reconocido en el Derecho internacional general. En cambio, es el resultado de facto del hecho de que el Derecho internacional otorga a los funcionarios diplomáticos ciertas inmunidades respecto de la jurisdicción local, como la inmunidad de sus residencias oficiales y oficinas. Si bien pueden alegarse motivos humanitarios, políticos o de otra naturaleza para conceder asilo diplomático, una vez que el refugiado ingresa a la misión, el Estado receptor se enfrenta a un dilema insoluble. Suponiendo que el Estado asilante no entregue a la persona, el Estado receptor puede detenerlo solamente cometiendo una violación de la inmunidad de los locales diplomáticos o, posiblemente, por la ruptura de relaciones diplomáticas. El hecho es que tales medidas extremas se consideran un precio demasiado alto a pagar por la aprehensión del asilado ${ }^{17}$.

13. Pareciera haber consenso en que el Estado acreditante puede, cuando exista peligro inmediato para la vida o la seguridad de una persona o grupo de personas, otorgar una protección limitada y temporal en sus misiones diplomáticas sobre la base del Derecho internacional consuetudinario ${ }^{18}$. Pero aún en los casos en que por motivos humanitarios se admite esa protección,

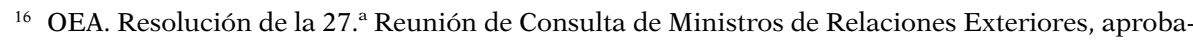
da durante la sesión plenaria celebrada el 24 de agosto de 2012, doc. RC.27/RES.1/12 rev. 3.

17 Ronning, C. N., Diplomatic Asylum. Legal Norms and Political Reality in Latin American Relations, La Haya, Martinus Nijhoff, 1965, p. 22.

18 Denza, E., Diplomatic Law. Commentary on the Vienna Convention on Diplomatic Relations,

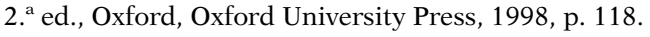


se la considera «un derecho de refugio temporal» ${ }^{19}$ y no asilo diplomático. Consecuentemente, como toda medida cautelar, es de naturaleza provisoria y debe cesar en el momento en que desaparecen los motivos que la ocasionaron, es decir, cuando deje de existir el peligro o cuando exista la posibilidad de que la persona sea objeto de un juicio ordinario, imparcial y con las garantías del debido proceso ${ }^{20}$. El mantenimiento, fuera de los límites de tiempo normales de una persona refugiada en los locales de una Embajada, se convierte en un abuso de los privilegios e inmunidades diplomáticas.

14. En 1974, la Asamblea General de las Naciones Unidas (AGNU) adoptó la Resolución 3321 (XXIX) ${ }^{21}$ por la que invitó a los Estados miembros a expresar su opinión sobre la materia y le solicitó al secretario general (SGNU) que elaborara un informe al respecto. Sobre la base de las opiniones vertidas por tan solo 25 Estados, el SGNU preparó un informe que elevó a la AGNU 22 . El informe proporcionó una reflexión detallada sobre el concepto de asilo diplomático y su evolución ${ }^{23}$, a la vez que confirmó el carácter regional de la práctica del asilo diplomático ${ }^{24}$. De los 25 Estados que dieron a conocer sus opiniones, solo siete se mostraron a favor de la elaboración de una convención internacional al respecto. Esto fue lo máximo que la organización pudo avanzar en su esfuerzo por desarrollar el tema. Consecuentemente, el examen ulterior del tema se pospuso indefinidamente, como quedó reflejado en la Resolución 3497 (XXX) ${ }^{25}$, adoptada el 15 de diciembre de 1975.

15. Hasta la fecha, no se ha adoptado ninguna convención universal sobre el asilo diplomático, como así tampoco la CDI ha redactado un proyecto de artículos sobre esta cuestión. Se ha afirmado que «la gran mayoría de los Estados no aceptan el asilo diplomático ni tienen que soportar su invocación ${ }^{26}$ y existe consenso en que no hay una norma del Derecho internacional consuetudinario general que reconozca el derecho de los Estados a otorgar el asilo diplomático ${ }^{27}$.

19 CAhIER, P., Derecho diplomático contemporáneo, Madrid, Rialp, 1965, p. 284.

20 Esta es la solución que adoptan expresamente tanto las Convenciones Americanas sobre Asilo Diplomático (art. III), Asilo Territorial, como la Convención de Ginebra sobre el Estatuto de los Refugiados de 1951 (cláusula 1F), que han incluido cláusulas de exclusión o cese que obligan a denegar una solicitud de asilo o de refugio, o a suspenderlo, cuando el solicitante ha cometido delitos comunes graves, o su conducta es contraria a los principios y propósitos establecidos en la Carta de las Naciones Unidas.

21 AGNU. Res. 3321 (XXIX). Cuestión del asilo diplomático, adoptada en la 2319. a sesión plenaria, el 14 de diciembre de 1974.

22 AGNU. Informe del Secretario General. Cuestión del asilo diplomático, 22 de septiembre de 1975, Doc. A/10139 (parte I) y (parte I) /Add. l y A/10139 (parte II).

${ }^{23}$ CAHIER, P., op. cit., nota 19, p. 283; Behrens, P., op cit., nota 11, p. 323.

24 Goodwin-Gill, G. S. y McAdam, J., The Refugee in International Law, 3. ${ }^{\text {a }}$ d., Oxford, Oxford University Press, 2007, p. 356.

25 AGNU. Res. 3497 (XXX). Cuestión del asilo diplomático, adoptada en la 2440. ${ }^{a}$ sesión plenaria, el 15 de diciembre de 1975.

${ }_{26}$ Mangas Martín, A., «Una norma limitada», El Mundo, 18 de agosto de 2012; en el mismo sentido Remiro Brotons, A., "Siete claves para entender el asilo de Julian Assange», Terra Noticias, 17 de agosto de 2012; YÁÑEZ-BARNUEVo, J. A., «Assange: o diálogo o años en la embajada», El País, 7 de septiembre de 2012.

27 Von Glahn, G., Law Among Nations. An Introduction to Public International Law, Boston, 7. a ed., Allyn and Bacon, 1996, p. 240; RonNING, op. cit., nota 17, pp. 50-51; RossitTo, A. M., «Diplomatic Asy- 
16. Como señala Den Heijer, de la inexistencia de una norma que fundamente el asilo diplomático no se deduce que todas las concesiones de asilo diplomático deben considerarse ilegítimas. La ausencia de un derecho de asilo diplomático simplemente implica que su concesión queda sometida a la soberanía territorial y, con ello, a la aprobación o aquiescencia del Estado receptor. Esto significa que si las autoridades territoriales no se oponen a su otorgamiento, este es perfectamente legal. Ello podría explicar también, por ejemplo, por qué algunos Estados europeos han concedido en ocasiones el asilo diplomático en los países latinoamericanos en circunstancias que se correspondían con el uso local y que tal vez podrían ser consideradas como que contaban con la aquiescencia o aceptación del Estado receptor ${ }^{28}$.

\subsubsection{El asilo en América Latina}

17. El Congreso Sudamericano de Montevideo reconoció el derecho de asilo en Legaciones y buques de guerra ${ }^{29}$. En ese marco, se adoptó el Tratado de Derecho Penal Internacional de $1889^{30}$, que, contiene disposiciones que se refieren tanto al asilo territorial como al diplomático. En 1928, los países de la región adoptaron Convención sobre Asilo ${ }^{31}$ y cinco años después, la Convención sobre Asilo Político ${ }^{32}$. Posteriormente, en 1939, se adoptó el Tratado sobre Asilo y Refugio Políticos ${ }^{33}$. De estos tres tratados se desprende que el asilo diplomático solo puede concederse en situaciones urgentes y por el periodo indispensable para garantizar la seguridad de la persona que lo solicita; que los Estados solo pueden otorgar asilo diplomático a personas buscadas por razones políticas, en contraposición a los delincuentes comunes; y que el Estado territorial puede solicitar en todo momento que la persona que recibe el asilo sea retirada de su territorio. Sin embargo, de estos acuerdos no surge un derecho individual a recibir asilo y los Estados requeridos, por tanto, gozan de la potestad de conceder o denegar el asilo.

18. Las normas adoptadas posteriormente en el plano interamericano estuvieron fuertemente influenciadas por los casos sustanciados ante la Corte Internacional de Justicia (CIJ) en materia de asilo diplomático: los asuntos relativos al Derecho de asilo (1950) ${ }^{34}$, y la Demanda de interpretación de

\footnotetext{
lum in the United States and Latin America: A Comparative Analysis», Brooklyn Journal of International Law, vol. 13, 1987, núm. 1, pp. 111-135, p. 113; MoRgENSTERN, F., "Extra-Territorial” Asylum», BYBIL, vol. 25, 1948, pp. 236-261, pp. 242-243.

28 Den HeiJer, M., «Diplomatic Asylum and the Assange Case», Leiden Journal of International Law, vol. 26, 2013, pp. 399-425, p. 409.

29 Antokoletz, D., Manual Diplomático y Consular, Buenos Aires, Librería La Facultad, 1928, vol. I, p. 176.

30 Firmado en Montevideo, el 23 de enero de 1889, entró en vigor el 11 de diciembre de 1894.

31 Firmada en La Habana, el 20 de febrero de 1928.

32 Firmada en Montevideo, Uruguay, el 26 de diciembre de 1933.

33 Adoptado en Montevideo, Uruguay, el 4 de agosto de 1939.

34 CIJ, «Derecho de asilo (Colombia c. Perú)»(1950), de 20 de noviembre de 1950.
} 
la sentencia de 20 de noviembre de $1950(1950)^{35}$ y Haya de la Torre (1951) ${ }^{36}$. El 3 de enero de 1949 el Jefe del Partido Aprista Peruano, Víctor Raúl Haya de la Torre, peruano requerido por las autoridades nacionales de su país acusado de haber instigado el golpe militar de 1948, fue asilado en la misión diplomática de Colombia. Haya de la Torre ingresó en la residencia del Embajador colombiano Echevarría Cortés aduciendo que su vida estaba en peligro por la persecución política del gobierno de su país e inmediatamente solicitó el asilo, el cual se le concedió. El Gobierno peruano reclamaba la entrega de Haya de la Torre, dado que lo consideraba «un criminal de delito común, y no de un refugiado político capacitado para acogerse al asilo». Colombia juzgaba que solo a ella le correspondía calificar el asilo y se negaba a entregar al político asilado. Fue el comienzo de una confrontación jurídica que duró cinco años y que mantuvo a Haya retenido en la Embajada de Colombia en Lima, ya que Perú no le concedió el salvoconducto. En el fallo de 20 de noviembre de 1950, la CIJ, rechazando la calificación de delito común, efectuada por el Gobierno peruano al afirmar que la rebelión militar no podía considerarse uno de ellos, concluyó que no se daban las condiciones necesarias para el asilo diplomático al no poderse oponer al proceso incoado ante las autoridades judiciales internas peruanas. En esta providencia, la CIJ expresó que:

«El asilo en la forma que es practicado en América Latina es una institución que, en gran medida, debe su desarrollo a factores extra-legales. Las relaciones de buena vecindad entre las repúblicas, los diferentes intereses políticos de los gobiernos, han favorecido el reconocimiento mutuo del asilo, más allá de cualquier sistema jurídico claramente definido. Aun si la Convención de La Habana, en particular, representara una reacción indiscutible contra ciertos abusos en la práctica, de ninguna manera tiende a limitar la práctica del asilo como puede derivarse de acuerdos entre gobiernos interesados inspirados por sentimientos mutuos de tolerancia y buena voluntad» ${ }^{37}$.

19. En el fallo de 1951, mientras llegaba a la conclusión que el asilo debió haber cesado tras su pronunciamiento anterior, reconocía que Colombia no estaba obligada a entregar a Haya de la Torre, todo ello como consecuencia de que la entrega no representa, decía el tribunal, «el único modo de poner fin al asilo». Los fallos de la CIJ fueron duramente criticados y no contribuyeron a solucionar la controversia, que solo pudo resolverse en virtud de un acuerdo directo entre las partes.

20. La aprobación de la Convención sobre Asilo Diplomático ${ }^{38}$, celebrada en el ámbito de la OEA en Caracas en 1954, tiene como precedente esos casos y procura delinear con mayor claridad la figura.

\footnotetext{
35 CIJ, «Demanda de interpretación de la sentencia del 20 de noviembre de 1950 (Colombia c. Perú)» (1950), del 27 de noviembre de 1950.

36 CIJ, «Haya de la Torre (Colombia c. Perú)»(1951), de 13 de noviembre de 1951.

37 CIJ, «Derecho de asilo (Colombia c. Perú)» (1950), de 20 de noviembre de 1950, p. 24, in fine. Traducción del autor.

38 Firmada en Caracas, el 28 de marzo de 1954.
} 


\subsection{La práctica estatal}

21. De una revisión somera de la práctica estatal a nivel universal, se desprende que la mayoría de los países rechazan formalmente esta costumbre, o al menos cualquier noción de que representa una obligación legal, con excepción de los países latinoamericanos donde la práctica del asilo diplomático está sólidamente arraigada ${ }^{39}$. En el resto del mundo, por lo general, únicamente se admite el asilo en casos de motivos políticos, razones humanitarias e impedimento de violaciones de derechos humanos. De no mediar un riesgo importante en este sentido, el Estado acreditante estaría actuando de manera ilícita al interferir en las atribuciones soberanas inherentes al Estado receptor.

22. La CIJ, en el asunto Haya de la Torre mencionado, puso de relieve que:

«Los hechos puestos en conocimiento del Tribunal revelan una tal incertidumbre y contradicción, tanta fluctuación y discrepancia en el ejercicio del asilo diplomático y en los criterios oficiales expuestos en diferentes ocasiones, se observa una tal falta de continuidad en la rápida sucesión de convenios sobre el asilo, ratificados por varios Estados y rechazados por otros, y la práctica ha sufrido en tal alto grado la influencia de consideraciones de oportunismo político en los varios casos que se han presentado, que no es posible discernir en todo ello un uso uniforme y constante» ${ }^{40}$.

23. Estados Unidos y los países europeos, por lo general, no reconocen el derecho de asilo diplomático ${ }^{41}$. La negativa expresa de Checoslovaquia, Suiza y Luxemburgo puede verse en los trabajos preparatorios de la CDI ${ }^{42}$. Las normas europeas referidas a la acogida de los solicitantes de protección internacional expresamente excluyen de su ámbito de aplicación a los solicitantes de asilo diplomático ${ }^{43}$. Una clara diferenciación entre el asilo territorial y el asilo diplomático, se desprende de la posición de Alemania y Estados Unidos, quienes se negaron a conceder asilo diplomático al grupo denominado «Durban Six» en Sudáfrica ${ }^{44}$. Los Gobiernos francés y holandés se unieron a los de Estados Unidos y Alemania en su decisión de denegar la petición.

24. Numerosos otros países europeos también rechazan la doctrina del asilo diplomático. En octubre de 1996, el gobierno suizo informó a su parlamento que las misiones suizas no pueden conceder asilo diplomático y que

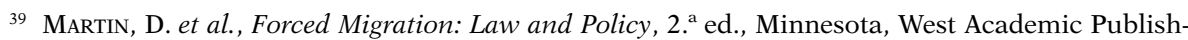
ing, 2013, p. 60 .

40 CIJ, «Derecho de asilo (Colombia c. Perú)» (1950), op. cit., p. 276. Traducción de Casanovas La

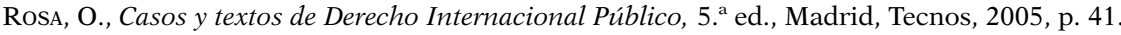

${ }^{41}$ KleIner, J., Diplomatic Practice: Between Tradition and Innovation, Singapur, Imperial College Press, 2009, p. 167 .

42 CDI, op. cit., p. 2.

43 A título de ejemplo puede verse la Directiva 2013/33/UE, del Parlamento Europeo y del Consejo, de 26 de junio, por la que se aprueban normas para la acogida de los solicitantes de protección internacional (texto refundido).

44 Riveles, S., «Diplomatic Asylum as a Human Right: The Case of the Durban Six», Human Rights Quarterly, vol. 11, 1989, núm. 1, pp. 140-142; JEFFERY, A. J., «Diplomatic Asylum: Its Problems And Potential As A Means Of Protecting Human Rights», South African Journal on Human Rights, vol. 1, 1985, núm. 1, pp. 10-30. 
«Suiza se opone también al otorgamiento de asilo por parte de las embajadas extranjeras acreditadas en Berna» ${ }^{45}$. En 1993, Suecia y Finlandia se negaron a conceder asilo diplomático a siete timorenses que habían ingresado en sus embajadas en Yakarta, en medio de un operativo orquestado por el Gobierno indonesio ${ }^{46}$. En su respuesta a la solicitud del SGNU, Suecia expresó que no reconoce el asilo diplomático "como una institución jurídica especial en sí misma», aunque "por razones humanitarias, debería considerarse legítimo que las misiones diplomáticas concedieran protección en sus locales en [...] situaciones de excepción ${ }^{47}$. Francia no reconoce el derecho a conceder asilo en sus embajadas, con la excepción de sus embajadas en América Latina ${ }^{48}$.

25. La práctica española ha variado con el transcurso del tiempo y las circunstancias. Inicialmente, se admitió la existencia del derecho de asilo diplomático como institución reconocida en la comunidad hispánica de naciones $^{49}$, particularmente en el contexto de la guerra civil española ${ }^{50}$. Posteriormente, esa práctica parece haber variado, al menos cuando debe ser aplicada fuera del marco hispanoamericano, como surge del caso del sargento Venancio Mikó ${ }^{51}$. España ratificó su posición en materia de asilo diplomático en una respuesta a una pregunta formulada por un parlamentario sobre el caso Assange. En esa oportunidad, expresó que:

«El Gobierno manifiesta que es necesario señalar que el "asilo diplomático", que se le ha otorgado al fundador de WikiLeaks, puede definirse como la protección otorgada por el Estado a una persona que es objeto de persecución política o ideológica y que se refugia en los locales de la misión diplomática acreditada en otro Estado. Se trata de una institución de Derecho internacional iberoamericano que ha sido codificada en varios instrumentos convencionales, siendo el más importante la Convención de Caracas de 28 de marzo de 1954. Existe, además, una costumbre regional en dicha zona. Al no tratarse de una institución de Derecho internacional general, su ámbito de acción queda circunscrito a Iberoamérica. Además, España no reconoce el asilo diplomático como un derecho. Por el contrario, España "estima que la pretensión de ejercerlo lesiona la soberanía del Estado en cuya representación diplomática se pretende refugiar" ${ }^{52}$.

45 Dembinski, L., The Modern Law of Diplomacy. External missions of states and international organizations, Dordrecht, Martinus Nijhoff Publishers, 1988, p. 249.

46 Robinson, G., "Human Rights History from the Ground Up: The Case of East Timor», en STERN, S. J. y Straus, S., The Human Rights Paradox: Universality and Its Discontents, Madison, University of Wisconsin Press, 2014, pp. 31-60, p. 45.

47 AGNU, Informe del Secretario General. Cuestión del asilo diplomático, op. cit., p. 28.

48 Véase «France: Condition d'octroi de l'asile diplomatique (1er Septembre 1970)», Revue Générale de Droit International Public, 1971, pp. 849-850. Asimismo, puede verse DupuY, P. M., «La position française en matière d'asile diplomatique», Annuaire français de droit international, vol. 22, 1976, pp. 743-755, p. 747.

49 Barcia Trelles, C., Ponencia, Actas del Primer Congreso del Instituto Hispano Luso Americano de Derecho Internacional, Madrid, 1951, t. I, pp. 207-314; citado por CAHIER, P., op. cit., nota 19, p. 285, nota $46-1$.

50 Véase Fernández Liesa, C. R., La guerra civil española y el ordenamiento jurídico internacional, Navarra, Civitas, Thomson Reuters, 2014.

51 PASTOR Ridruejo, A., op. cit., nota 2, p. 239.

52 BOCG, Congreso de los Diputados, serie D, núm. 178, de 15 de noviembre de 2012, p. 222. 
26. La posición estadounidense, que no ha cambiado, puede extraerse de su respuesta al pedido del SGNU. Allí expresó: «1) que el asilo diplomático y el asilo territorial son dos nociones completamente diferentes; 2) que los principios que se afirman con la base del concepto de asilo diplomático son numerosos, no siempre están precisados en forma congruente por sus partidarios y, en aspectos fundamentales, no se ajustan a normas universalmente aceptadas de Derecho internacional, y 3) que la práctica digna de mención de asilo diplomático que ha existido en América Latina ha funcionado en gran medida no solamente mediante tratados, sino mediante acuerdos comunes no precisados» ${ }^{53}$. Las embajadas de Estados Unidos están autorizadas a conceder refugio temporal por razones humanitarias en circunstancias extremas o excepcionales cuando la vida o seguridad de una persona se pone en peligro inmediato, como puede ser la persecución por una turba ${ }^{54}$. Sin embargo, los Estados que ocasionalmente conceden refugio temporal en sus misiones diplomáticas no siguen una pauta única y uniforme, sino que adaptan sus acciones a cada situación. Ello impide que se genere una práctica estatal también en esta materia ${ }^{55}$.

27. En determinadas ocasiones, la práctica estadounidense se ha alejado de esta política estatal y los diplomáticos estadounidenses concedieron asilo en sus representaciones diplomáticas en varias situaciones que no involucraban casos de violencia popular ${ }^{56}$. Entre ellos, a título de ejemplo puede mencionarse los siguientes casos: el cardenal Jósefz Mindszenty se asiló en la Embajada estadounidense al fracasar la revolución húngara de $1956^{57}$; los disidentes pentecostales rusos que ingresaron en la Embajada de los Estados Unidos en Moscú en 1978 ${ }^{58}$; el asilo a Fang Lizhy, a su esposa, Li Shuxian, y al hijo de ambos después de que el gobierno chino aplastara el movimiento prodemocrático en la Plaza de Tiananmen en junio de $1989^{59}$. Más recientemente, en abril de 2012, el activista chino ciego Chen Guangcheng escapó de su arresto domiciliario y buscó refugio en la embajada de los Estados Unidos en Beijing ${ }^{60}$.

28. Es en la historia política de América Latina donde el derecho de asilo diplomático ha sido ejercido y reconocido en innumerables oportunidades.

53 AGNU, Informe del Secretario General. Cuestión del asilo diplomático, op. cit., Parte I, Add. 1, p. 2.

${ }^{54}$ NASH, M. L., "Contemporary Practice of the United States Relating to International Law. Diplomatic Asylum», American Journal of International Law, vol. 75, 1981, núm. 1, p. 142.

55 KLEINER, op. cit., nota 41, p. 178.

56 Von Glahn, G. y Taulbee, J. L., Law Among Nations: An Introduction to Public International

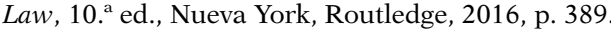

57 Vieira, M. A., Derecho de Asilo Diplomático (Asilo Político), Biblioteca de Publicaciones Oficiales de la Facultad de Derecho y Ciencias Sociales de la Universidad de la República, Sección III-CXVIII, Montevideo, 1961.

58 BuRns, J. F., "5 Pentecostals To Leave Soviet: 5 Spent 5 Years in U.S. Embassy», The New York Times, 27 de junio de 1983.

59 Rubin, A. P., «Diplomatic Asylum and Fang Lizhi», Diplomacy \& Statecraft, vol. 1, 1990, núm. 1, pp. 84-89.

60 JACoBs, A. y ANSFIELD, J., "Challenge for U.S. after Escape by China Activist», New York Times, 27 de abril de 2012. 
Badeni recuerda que «a él acudieron muchos de los adversarios de Juan Manuel de Rosas, e incluso él mismo cuando, al ser depuesto el 3 de febrero de 1852, se asiló en la legación británica de Buenos Aires y fue permitido su traslado a un buque inglés que lo condujo a Inglaterra ${ }^{61}$. Ya con anterioridad a casos suscitados ante la Corte Internacional de Justicia (CIJ), puede recordarse la actuación del embajador argentino ante el Reino de España, Daniel García-Mansilla, quien en julio de 1936 puso en práctica en España el derecho de asilo ${ }^{62}$. Poco tiempo después de adoptarse la Convención de Caracas, Juan Domingo Perón buscó asilo en Paraguay luego de una cruenta asonada militar que lo sacó del poder en septiembre de $1955^{63}$. El golpe de Estado, que provocó la caída del régimen del Presidente Allende en Chile en 1973, ocasionó que cientos de perseguidos políticos buscaran asilo en las diversas representaciones diplomáticas extranjeras ${ }^{64}$. En 1976, con posterioridad al golpe de Estado del 24 de marzo, el ex Presidente argentino Héctor J. Cámpora y Juan Manuel Abal Medina, al igual que muchos otros ciudadanos argentinos, tuvieron que solicitar asilo en la Embajada de México en Buenos Aires ${ }^{65}$.

29. Entre los casos más recientes de asilo diplomático pueden mencionarse el del presidente de la Confederación de Trabajadores de Venezuela, quien en marzo de 2003 se refugió en la embajada costarricense en Caracas $^{66}$. El Presidente ecuatoriano Lucio Gutiérrez solicitó el asilo diplomático al embajador brasileño en Quito en abril de $2005^{67}$. En 2009, el destituido y expulsado Presidente de Honduras Manuel Zelaya, luego de reingresar a Honduras, solicitó y recibió asilo en la Embajada de Brasil en Tegucigalpa, motivando que el Gobierno hondureño demandara a Brasil ante la CIJ por violación del principio de no intervención para, posteriormente, desistirla ${ }^{68}$. En junio de 2012, el Gobierno brasileño concedió asilo político al Senador opositor boliviano Roger Pinto.

30. El Reglamento para las representaciones diplomáticas de la República Argentina (RRDRA) ${ }^{69}$ contiene un capítulo dedicado al derecho de asilo di-

\footnotetext{
61 BADENI, op. cit.

62 Al respecto, puede verse Figallo, B., Diplomáticos y marinos argentinos durante la crisis española: los asilos de la guerra civil, Buenos Aires, Librería Histórica, 2007, pp. 58 y ss.

63 SÁnchez Bonifato, C. L., "Cuando a Perón no lo quería ni Stroessner», La Nación, 31 de octubre de 1999.

${ }^{64}$ CAmacho, F., «Los asilados de las embajadas de Europa Occidental en Chile tras el golpe militar y sus consecuencias diplomáticas: El caso de Suecia», European Review of Latin American and Caribbean Studies, vol. 81, 2006, pp. 21-41, 147-148, 150.

${ }^{65}$ Lecitra, M., El asilo diplomático en el Cono Sur (1970-1980). Los casos de Héctor Cámpora y Juan Manuel Abal Medina, Buenos Aires, UAI, marzo de 2013.

66 «Recibe salvoconducto líder sindicalista venezolano», El Universal, México, 26 de marzo de 2003.

67 Ministerio de Relaciones Exteriores de Brasil, Ficha País. República del Ecuador, disponible en http://www.itamaraty.gov.br/es/ficha-pais/11276-republica-del-ecuador (consultada el 14 de abril de

68 Arredondo, R., "Corte Internacional de Justicia: Honduras v. Brasil y el "principio de no intervención”», Agenda Internacional, vol. 20, Buenos Aires, diciembre de 2009, pp. 60-75.

${ }^{69}$ Decreto núm. 7.743/63. Reglamento para las representaciones diplomáticas de la República Argentina. Aprobado el 17 de septiembre de 1963.
} 2017). 
plomático (cap. XIII), cuyo conocimiento es relevante para conocer la opinio juris de la Argentina en materia de asilo. Allí, se le reconoce a este instituto un «carácter excepcional y restrictivo, pues importa una derogación al ejercicio normal de la soberanía del Estado receptor».

\section{EL CASO ASSANGE}

\subsection{Antecedentes}

31. Julian Assange, de nacionalidad australiana, se encuentra desde el 19 de junio de 2012 en la sede de la Embajada de Ecuador ante en el Reino Unido, oportunidad en la que solicitó asilo a ese país para evitar ser extraditado a Suecia ${ }^{70}$. Antes de ser detenido trabajaba como editor y periodista, siendo muy respetado. En su posición como redactor jefe de WikiLeaks, Assange obtuvo un notable reconocimiento internacional por su papel en la difusión de información que no estaba disponible para el público masivo. Como resultado de sus esfuerzos para crear una mayor transparencia en los medios de comunicación y exponer numerosas transgresiones de derechos humanos, se convirtió en una suerte de celebridad internacional, aunque en circunstancias inusuales ${ }^{71}$.

32. El 20 de noviembre de 2010 se emitió una orden internacional de arresto sobre él ${ }^{72}$, a fin de ser interrogado en Suecia respecto de acusaciones de violación, abuso sexual y coerción ilegal que pesaban en su contra ${ }^{73}$. Menos de tres semanas más tarde, el 8 de diciembre de 2010, Assange se entregó a la policía británica, lo que provocó una larga batalla legal ante los tribunales de ese país que duró dieciocho meses. El caso aparentemente había llegado a su conclusión en mayo de 2012, cuando la Corte Suprema del Reino Unido determinó que «la solicitud de extradición sueca había sido realizada conforme a derecho » ${ }^{74}$. Después de que un último intento por reabrir el caso fuera desestimado, se les dio a los funcionarios británicos diez días para trasladar a Assange a Suecia ${ }^{75}$. En lugar de agotar sus alternativas lega-

${ }^{70}$ Existe una abundante bibliografía sobre los antecedentes del caso, por lo que no abundaremos sobre ello en este trabajo. Al respecto, entre otros, pueden consultarse los trabajos de: LAVANDER, T., «Using the Julian Assange Dispute to Address International Laws Failure to Address the Right of Diplomatic Asylum», Brooklyn Journal of International Law, vol. 39, 2014, núm. 1, pp. 443-486; ARBUETVignal, H., El caso Assange en el derecho internacional público, Consejo Uruguayo para las Relaciones Internacionales, Estudio núm. 5/12, 9 de agosto de 2012.

${ }^{71}$ LAVANDER, T., op. cit., nota 70.

72 A fin de ejecutar la orden de detención, la fiscal sueca dictó una orden de detención internacional y una orden de detención europea. Véase la Decisión Marco del Consejo 2002/584/JAI del Consejo de la Unión Europea.

73 «Timeline: Sexual Allegations Against Assange in Sweden», BBC News, disponible en $h t t p: / / w w w$. bbc.co.uk/news/world-europe-11949341 (consultada el 13 de abril de 2017).

74 «Julian Assange Loses Extradition Appeal at Supreme Court», BBC News, disponible en http:// www.bbc.com/news/uk-18260914 (consultada el 13 de abril de 2017).

75 Corte Suprema del Reino Unido. Assange (Appellant) v The Swedish Prosecution (2012), UKSC 22, 30 de mayo de 2012; "Supreme Court Dismisses Assange Appeal Bid», BBC News, disponible en http://www.bbc.com/news/world-18446295 (consultada el 20 de abril de 2017). 
les mediante una apelación ante el Tribunal Europeo de Derechos Humanos $(\mathrm{TEDH})^{76}$, Assange buscó asilo en la embajada ecuatoriana en Londres en junio de $2012^{77}$. Alegando sus temores de persecución política y la posibilidad de la pena de muerte si fuera extraditado a los Estados Unidos, Ecuador concedió formalmente asilo a Assange el 16 de agosto de $2012^{78}$. Suecia y el Reino Unido criticaron la decisión de Ecuador y se comprometieron a evitar que Assange saliera de Gran Bretaña.

\subsection{Los fundamentos de la concesión de asilo y sus respuestas}

33. El comunicado del Gobierno de Ecuador alega que el señor Assange tomó la decisión de solicitar el asilo y protección de Ecuador

«por las acusaciones que, según manifiesta, le han sido formuladas por supuesto "espionaje y traición", con lo cual este ciudadano expone el temor que le infunde la posibilidad de ser entregado a las autoridades de los Estados Unidos de América por las autoridades británicas, suecas o australianas, pues aquel es un país, señala el señor Assange, que lo persigue debido a la desclasificación de información comprometedora para el Gobierno estadounidense» ${ }^{79}$.

34. A la luz de estos acontecimientos, el Gobierno de Ecuador, «acogiéndose a las normas sobre Asilo Diplomático vigentes», decidió conceder el asilo diplomático al encontrarse Assange sin la debida protección y auxilio que debía recibir de parte de Australia, ante la presunción de Gran Bretaña, Suecia y Estados Unidos de América no respetarían las convenciones y tratados internacionales y darían prioridad a sus leyes internas, «contraviniendo normas expresas de aplicación universal» ${ }^{80}$; y, de esta manera, se iniciaría una cadena de sucesos que haría factible su extradición a Estados Unidos.

35. Adicionalmente, Ecuador fundamentó su decisión en su legislación interna (Constitución Nacional -art. 41- y la Ley Orgánica del Servicio Exterior ecuatoriano de 2006 - art. 4.7-) y en «el conjunto de principios,

${ }^{76}$ No se entiende bien por qué Assange siguió este camino. Una posibilidad es que tuviera información acerca de que cualquier queja o solicitud de medidas provisionales ante el TEDH habría sido considerada prematura por este Tribunal, ya que todavía tendría posibilidad de presentar esas solicitudes una vez que fuera extraditado a Suecia. También es factible que Assange considere que el TEDH sería igual de servil a los Estados Unidos como las cortes de Suecia, el Reino Unido y Australia. Cfr. DEN HEIJER, op. cit., nota 28, pp. 418-19.

77 Mena Erazo, P., «Assange pide asilo político en la embajada de Ecuador de Londres», El País, 20 de junio de 2012.

78 Neuman, W. y Ayala, M., «Ecuador Grants Asylum to Assange, Defying Britain», New York Times, 16 de agosto de 2012, disponible en http://www.nytimes.com/2012/08/17/world/americas/ecuador-to-letassange-stay-in-its-embassy.html (consultada el 13 de abril de 2017); y «Ecuador otorga asilo político a Assange y abre un conflicto diplomático con Reino Unido», RTVE.es, 17 de agosto de 2012, http://www. rtve.es/noticias/20120817/ecuador-otorgaasilo-assange-conflicto-reino-unido/557404.shtml (consultada el 13 de abril de 2017).

${ }_{79}$ Ministerio de Relaciones Exteriores, Comercio e Integración del Ecuador, Comunicado núm. 42, "Declaración del Gobierno de la República del Ecuador sobre la solicitud de asilo de Julian Assange», disponible en http://www.ecuador.org/blog/? $p=2117$ (consultada el 13 de abril de 2017).

${ }^{80}$ Cursiva añadida. 
normas, mecanismos y procedimientos previstos en los instrumentos internacionales de derechos humanos (sean de carácter regional o universal), que contemplan entre sus disposiciones el derecho de buscar, recibir y disfrutar del asilo por motivos políticos». Asimismo, Ecuador sostuvo la primacía de las normas internacionales sobre la legislación doméstica de cualquier Estado.

36. El Reino Unido rechazó las alegadas imputaciones de amenazas del Reino Unido a la Embajada de Ecuador en Londres y presentó la visión de su país respecto de los hechos vinculados a la detención y juzgamiento de Assange, manifestando que Gran Bretaña reconoce que Ecuador y muchos otros Estados miembros de la OEA son Partes de la Convención de Caracas de 1954 sobre Asilo diplomático y que esta Convención «establece el derecho entre sus Estados miembros a conceder asilo diplomático en determinadas circunstancias. Sin embargo, el Reino Unido no forma parte de esta Convención y no existe base legal por la que el Reino Unido deba satisfacer la petición del gobierno de Ecuador para permitir al Sr. Assange abandonar el Reino Unido con seguridad». Por otra parte, desestimó las preocupaciones respecto a la posible extradición de Assange a los Estados Unidos, reafirmó su convicción en la imparcialidad del sistema judicial sueco y la protección otorgada al australiano por la Convención Europea sobre Derechos Humanos, el Derecho internacional y de la Unión Europea y legislación interna de su país ${ }^{81}$. Pocos días después de la concesión de asilo a Assange, la cuestión fue abordada por el Consejo de Ministros y Ministras de Relaciones Exteriores de UNASUR, que manifestó su solidaridad y respaldó la decisión ecuatoriana de conceder asilo diplomático a Assange ${ }^{82}$.

37. Algunos autores arguyen que, a pesar de que Ecuador estaría posiblemente incumpliendo las disposiciones del art. 41.3 de la CVRD, que establece que «los locales de la misión no deben ser utilizados de manera incompatible con las funciones de la misión», la concesión de asilo no justificaría la entrada de la policía británica a los locales de la Embajada ecuatoriana ${ }^{83}$. De todos modos, el Reino Unido sostiene que nunca amenazó con ingresar a esa representación, ya que está absolutamente comprometido con los principios de la CVRD y actúa de conformidad con ello ${ }^{84}$.

38. En mayo de 2017, la Fiscalía de Suecia decidió archivar la causa por presunta violación contra Julian Assange ${ }^{85}$. La decisión está fundada no en la

81 OEA, Doc. Ser.F/II.27 y RC.27/INF. 10/12.

82 Consejo de Ministros y Ministras de Relaciones Exteriores de UNASUR, «Declaración de Guayaquil en respaldo a la República del Ecuador», Guayaquil, 19 de agosto de 2012.

83 Duxbury, A., «Assange and the Law of Diplomatic Relations», ASIL Insights, núm. 32 (16), 11 de octubre de 2012.

${ }^{84}$ Véase la comunicación escrita del secretario de Asuntos Exteriores al Parlamento británico de 3 de septiembre de 2012 (Extradition Proceedings Against Julian Assange, Written Statement to UK Parliament by UK Foreign Secretary William Hague), 3 de septiembre de 2012.

85 FISCALÍA DE SUECIA, «The investigation against Julian Assange is discontinued», 19 de mayo de 2017, disponible en http://news.cision.com/aklagarmyndigheten/r/the-investigation-against-julian-assange-is-discontinued,c2269492 (consultada el 31 de mayo de 2017). 
inocencia de Assange, sino a las dificultades que su asilo ha generado para el procedimiento. El fundador de WikiLeaks consideró esta medida como una «importante victoria, aunque la guerra no ha terminado» ${ }^{86}$. En efecto, subsiste la posibilidad de que los Estados Unidos active una orden de detención, sobre la que el Reino Unido ha evitado pronunciarse ${ }^{87}$. Por su parte, la Policía británica ha emitido un comunicado expresando que tiene previsto detener al australiano si sale de la Embajada de Ecuador, ya que existe una orden judicial de detención vigente por no haberse presentado ante la corte de Westminster cuando fue citado, el 29 de junio de $2012^{88}$.

39. Al analizar el caso Assange, surgen tres cuestiones fundamentales: si Ecuador tiene derecho a conceder asilo, si el Reino Unido tiene derecho a terminar ese asilo y si Assange puede invocar un derecho a ser protegido contra alegadas injusticias en los Estados Unidos y otros países ${ }^{89}$. La respuesta a estas cuestiones dependerá de la interpretación que se dé al marco jurídico y a la práctica estatal previamente descriptas. Sin embargo, como se señala en el punto 4 infra, es improbable que la solución a este intríngulis provenga de la mera exégesis y aplicación de las normas y prácticas vigentes.

40. En 2014, el Grupo de Trabajo sobre la Detención Arbitraria del Consejo de Derechos Humanos de las Naciones Unidas (GTDA) recibió una presentación referida al fundador de WikiLeaks. Después de sustanciar el procedimiento correspondiente, el GTDA arribó a la conclusión de que «la privación de libertad de Julian Assange es arbitraria, porque contraviene los arts. 9 y 10 de la Declaración Universal de Derechos Humanos y los arts. 7, 9, párrs. 1, 3 y 4, 10 y 14 del Pacto Internacional de Derechos Civiles y Políticos, y se inscribe en la categoría III ${ }^{90}$, esto es aquellos casos donde hay «inobservancia, total o parcial, de las normas internacionales relativas al derecho a un juicio imparcial, establecidas en la Declaración Universal de Derechos Humanos y en los instrumentos internacionales pertinentes aceptados por los Estados interesados»" ${ }^{91}$. En virtud de ello, el GTDA requirió a «los Gobiernos de Suecia y el Reino Unido que evalúen la situación del Sr. Assange, garanticen su seguridad y su integridad física, faciliten el ejercicio de su derecho a la libertad de circulación de manera oportuna y velen por que disfrute plenamente de los derechos que le garantizan las normas internacionales en materia de reclusión». Adicionalmente, consideró que en atención las circunstancias del

\footnotetext{
86 Erlanger, S. y Anderson, C., «Julian Assange Rape Inquiry Is Dropped but His Legal Problems Remain Daunting», The New York Times, 19 de mayo de 2017, disponible en https://www.nytimes. com/2017/05/19/world/europe/julian-assange-sweden-rape.html (consultada el 31 de mayo de 2017).

87 Veáse el tweet de WikiLeaks, disponible en https://twitter.com/WikiLeaks/status/865497032722 530304 (consultada el 31 de mayo de 2017).

88 Metropolitan Police, «Statement on Julian Assange», 19 de mayo de 2017, disponible en http:// news.met.police.uk/news/statement-on-julian-assange-242877 (consultada el 31 de mayo de 2017).

89 Den HeIJER, op. cit., nota 28, p. 400.

90 Consejo de Derechos Humanos. Grupo de Trabajo sobre la Detención Arbitraria. Opinión núm. 54/2015 relativa a Julian Assange (Suecia y Reino Unido de Gran Bretaña e Irlanda del Norte), 6 de abril de 2016, p. 18. Doc. A/HRC/WGAD/2015/54.

${ }_{91}$ Consejo de Derechos Humanos. Grupo de Trabajo sobre la Detención Arbitraria. Folleto Informativo núm. 26, pp. 5-6.
} 
caso, se debería dar al fundador de WikiLeaks derecho efectivo a obtener reparación.

41. La decisión del GTDA fue recibida con sorna en el ámbito europeo, tanto por parte de especialistas como por los medios de prensa ${ }^{92}$. Las críticas a la opinión del GTDA toman como base el «Voto particular disconforme de Vladimir Tochilovsky», quien puso de manifiesto que Assange no es objeto de una privación arbitraria de la libertad, sino que voluntariamente se encuentra recluido en la Embajada de Ecuador en Londres, con el objeto de evitar la detención ordenada por la autoridad judicial sueca ${ }^{93}$. Asimismo, los reparos se centraron en periodos de tiempo sobre cuya naturaleza jurídica existe discrepancia ( $v$. gr. los días de detención previos a la libertad condicional, el periodo durante la libertad condicional y el tiempo en la Embajada de Ecuador) y sobre las condiciones de detención durante esos periodos. Por otra parte, se subrayó que en el mandato del Grupo de Trabajo no se encuentran incluidas las cuestiones relacionadas con el confinamiento voluntario de los prófugos, como el asilo y la extradición.

42. Concretamente, en lo que se refiere al asilo diplomático, el GTDA reprochó a las autoridades británicas y suecas que no hubiesen reconocido el asilo que Ecuador había concedido a Assange. El Reino Unido afirmó que el Gobierno de Ecuador concedió asilo diplomático, no asilo político, al fundador de WikiLeaks y lo hizo en virtud de la Convención sobre Asilo Diplomático de 1954. El Reino Unido entiende que de la decisión de Ecuador no se deriva ninguna obligación legal para el Reino Unido, ya que este país no es parte de esa Convención y no reconoce este tipo de asilo ni la costumbre existente ni su propia práctica (par. 41). Si los Estados estuvieran obligados a respetar las concesiones de asilo diplomático de otros Estados, se deduciría que la negativa a permitir que Assange dejara la Embajada sin molestias violaría su derecho a la libertad y la seguridad de la persona. Pero no existe tal obligación en virtud del Derecho internacional general y ni Suecia ni el Reino Unido son partes de la Convención sobre Asilo Diplomático ${ }^{94}$. En septiembre de 2016, una Corte de Apelación sueca confirmó, por octava vez, la vigencia de la orden de detención emitida seis años antes contra Assange ${ }^{95}$. El tribunal también sostuvo que la permanencia del australiano en la embajada ecuatoriana no puede ser considerada como una "privación ilegal de la libertad».

43. Lógicamente, los partidarios de Assange afirman que la opinión ${ }^{96} \mathrm{del}$ GTDA reivindica su posición y exigen que Suecia ${ }^{97}$ y el Reino Unido ${ }^{98}$ aban-

\footnotetext{
92 LAZARUS, L., «The United Nations Working Group on Arbitrary Detention decision on Assange: "ridiculous" or "justifiable"?», EJIL Talk, 9 de febrero de 2016; HAPPOLD, M., «Julian Assange and the UN Working Group on Arbitrary Detention Published», EJIL Talk, 5 de febrero de 2016.

93 GTDA, op. cit., Voto particular disconforme de Vladimir Tochilovsky, p. 19.

94 Happold, M., «Julian Assange and Diplomatic Asylum», EJIL Talk, 24 de junio de 2012.

95 Eachambadi, R., «Sweden court upholds arrest warrant for Julian Assange», Paper Chase, 16 de septiembre de 2016.

96 Las opiniones del GTDA son consideradas como no vinculantes. Sin embargo, la gacetilla de prensa distribuida en ocasión de la opinión sobre Assange sostiene expresamente lo contrario: «The 
donen los procedimientos en contra de Assange. Señalan que estos Estados, al negarse a seguir la opinión del Grupo de Trabajo, asumen una posición conflictiva ante el Derecho internacional. Sin embargo, tanto el Gobierno sueco como el Reino Unido han anunciado su desacuerdo con la opinión, subrayando que no tienen obligación legal de cumplirla.

\subsection{La solicitud de opinión consultiva a la Corte Interamericana de Derechos Humanos}

44. El 18 de agosto de 2016, el Gobierno de Ecuador presentó en la Secretaría de la Corte Interamericana de Derechos Humanos una solicitud de opinión consultiva sobre «la institución del asilo en sus diversas formas y la legalidad de su reconocimiento como derecho humano de todas las personas conforme al principio de igualdad y no discriminación ${ }^{99}$.

45. La solicitud abre con una serie de «consideraciones» que desde el inicio exhiben uno de los argumentos de Ecuador, al señalar que, en el caso de los perseguidos políticos, «ha sido frecuente la presentación de acusaciones de delitos comunes», con la finalidad de impedir que se les otorgue el asilo o se ponga fin a este y «someter a estas personas a medidas de carácter punitivo bajo la apariencia de procesos judiciales» (párr. 1). El fundamento legal se presenta en una extensa sección que abarca cuestiones del Derecho internacional de los derechos humanos, del derecho de los refugiados, del Derecho internacional humanitario y del Derecho internacional general. Los argumentos de Ecuador y la formulación de las cuestiones sometidas a la Corte pueden resumirse de la manera siguiente: $a$ ) Ecuador sostiene que el asilo tiene larga raigambre, caracterizada como «tradición latinoamericana del asilo", párr. 4), y se ha "transformado en derecho humano tras su consagración en diversos instrumentos de derechos humanos» (párrs. 2, 11); b) consecuentemente, se afirma que el asilo diplomático, el asilo territorial y el refugio comparten un núcleo básico; c) ese núcleo contenido básico se articula en obligaciones concretas de derechos humanos tal como el principio de no devolución (véanse párrs. 16, 17, entre otros), obligaciones de debido proceso como el deber de procesar individualmente cada solicitud de asilo, inter alia; d) Ecuador afirma que el incumplimiento de estos deberes también

Opinions of the Working Group on Arbitrary Detention are legally binding to the extent that they are based on binding international human rights law, such as the International Covenant on Civil and Political Rights (ICCPR). [...] The binding nature of its opinions derives from the collaboration by States in the procedure, the adversarial nature of is findings and also by the authority given to the WGAD by the UN Human Rights Council», disponible en http://www.ohchr.org/EN/NewsEvents/Pages/DisplayNews. aspx?NewsID $=17013 \&$ LangID $=E$ (consultada el 20 de abril de 2017).

${ }_{97}$ Véase https://twitter.com/jamesrbuk/status/695533002697392128 (consultada el 20 de abril de 2017).

98 Foreign \& Commonwealth OfFice, «El Reino Unido disputa la opinión del Grupo de Trabajo de Naciones Unidas sobre Julian Assange», Gacetilla de prensa, 5 de febrero de 2016.

99 Ministerio de Relaciones Exteriores y Movilidad de Ecuador, nota núm. 4-3-21j2016, San José, 18 de agosto de 2016. 
podría constituir una violación del derecho a la vida (párr. 36), la integridad personal (párr. 38) y la no discriminación (párr. 21), y e) en un intento por subrayar su carácter general, Ecuador señala que «el asilo otorgado por un Estado en el ejercicio de su soberanía, genera obligaciones internacionales no solo para el Estado asilante sino para la comunidad internacional, independientemente del derecho convencional que exista en esta materia» (párr. 14). Consecuentemente, define a estas obligaciones como erga omnes (párrs. 18, 28, 38, 49, 52) o como jus cogens (párrs. 22, 35, 38). Esta caracterización le permite a Ecuador expresar su verdadero argumento, que es doble naturaleza: i) que todos los Estados tienen un interés en esos compromisos y, por tanto, se encuentran obligados por ellos, y ii) que, por tanto, les está prohibido impedir que otro Estado cumpla con estas obligaciones como cuestión de Derecho internacional (párrs. 19, 20).

46. Ecuador afirma que el asilo es un acto de Estado. De ello, se desprende que goza del privilegio de inmunidad, «lo cual no permite a otro Estado cuestionar la conducta protectora del Estado asilante». Consecuentemente, «el Estado territorial debe respetar dicho acto de soberanía» (párr. 38), particularmente en lo que se refiere a la calificación de los delitos que se le imputan a la persona que solicita asilo, ya que «las denuncias contra quien solicita asilo o está en goce de este derecho, pueden ser desestimadas en el curso de la calificación respectiva si el Estado asilante considera que las eventuales acusaciones que tendría que enfrentar el asilado por la supuesta comisión de delitos comunes, tienen una intención política, ya que están vinculados al acto persecutorio» (párr. 40, in fine). De ello, se deriva el Derecho del Estado asilante a aplicar el principio de no devolución, ante las posibles consecuencias que el asilado pudiera sufrir en el caso de ser detenido (párrs. 44-46).

47. Asimismo, afirma que el asilo es un mecanismo de protección de los derechos humanos (párr. 50), que el «Estado ecuatoriano estima que los términos "medios de protección" reconocidos internacionalmente no hacen distinciones desfavorables entre las diversas modalidades que conciernen a la protección» (párr. 48) y, consiguientemente, tiene la obligación de adoptar las medidas apropiadas para la protección de esos derechos (párr. 51). De ello, sigue que, entre diversos regímenes jurídicos aplicables a una misma situación, debe elegirse la alternativa más favorable para la tutela de los derechos protegidos, es decir, «si a una situación son aplicables dos normas distintas, "debe prevalecer la norma más favorable a la persona humana" " (párr. 56).

48. A la luz de las consideraciones precedentes, Ecuador le solicita esencialmente a la Corte que se pronuncie acerca de si un Estado, particularmente uno «ajeno a determinada convención sobre asilo» o que "pertenezca a un régimen jurídico regional distinto» al que concedió el asilo, un grupo o individuo puede realizar actos o adoptar «una conducta que en la práctica signifique el desconocimiento de las disposiciones establecidas en los instrumentos de derechos humanos», «limite, disminuya o menoscabe cualquier forma de asilo», y cuáles deberían ser las consecuencias jurídicas de ello (párr. 58). 
49. Al momento de finalizar la redacción de este artículo, la Corte IDH decidió prorrogar hasta el 4 de mayo de 2017 el plazo límite establecido para la presentación de las observaciones escritas a la presentación realizada por Ecuador.

50. En su presentación, Ecuador busca fundamentar, desde el punto de vista jurídico, el derecho de asilo diplomático en normas del Derecho internacional de los derechos humanos, del derecho de los refugiados, del Derecho internacional humanitario y del Derecho internacional general. En ese intento, erróneamente a mi juicio, trata las instituciones del asilo diplomático y territorial como si fueran análogas. En efecto, contrariamente a lo que ocurre con el asilo territorial, el asilo diplomático no es considerado como un acto que se ajusta a una norma de Derecho internacional consuetudinario y ello se justifica por la diferencia fundamental que existe entre ambas figuras. Un Estado que concede asilo en su propio territorio ejerce uno de sus derechos soberanos en la esfera de competencia que le reconoce el Derecho internacional. En cambio, en el caso del asilo diplomático, quien busca protección se encuentra en el territorio del Estado que lo reclama.

51. Recurrir a la Convención de 1951 sobre el Estatuto de los Refugiados de 1951 tiene como inconveniente el hecho de que el art. $1 \mathrm{~F}(\mathrm{~b})$ de dicha convención expresamente dispone la exclusión de la condición de refugiado para aquellas personas que hayan cometido un "grave delito común» fuera del país de refugio antes de haber sido admitidos a él como refugiados ${ }^{100}$. Cabe recordar que Assange está acusado de violación, abuso sexual y coerción ilegal, lo que haría inaplicable la figura del refugiado, aunque Ecuador mantiene que esas causas han sido «armadas» para poder detener a Assange y, por tanto, no las toma en consideración. Por otra parte, las disposiciones de este acuerdo se aplican por lo general a personas que huyen de su propio país, a menos que la persona «se encuentre fuera del país de su nacionalidad y no pueda o [...] no quiera acogerse a la protección de tal país» ${ }^{101}$. En este sentido, es cuestionable porque Assange no buscó la protección del país de su nacionalidad sino la de un tercer Estado. Pero aun admitiendo que Assange tuviera el carácter de refugiado, es dudoso que esté amparado por el derecho fundamental de la Convención, esto es, el derecho de ser protegido contra una expulsión o devolución a un territorio donde su vida o su libertad peligre $^{102}$, como alega Ecuador insistentemente a lo largo de su solicitud de opinión, ya que difícilmente se pueda interpretar al acto de retirar a alguien de una embajada como una expulsión o devolución ${ }^{103}$.

52. Recurrir a las normas del Derecho internacional de los derechos humanos parecería ser una opción más plausible para Ecuador que invocar el

100 ACNUR, Documento sobre la aplicación de las cláusulas de exclusión: El artículo $1 F$ de la Convención de 1951 sobre el Estatuto de los Refugiados, Ginebra, 4 de septiembre de 2003, p. 21.

101 Cfr. el art. 1.A.2 de la Convención de 1951 sobre el Estatuto de los Refugiados.

102 Art. 33.1 de la Convención.

103 Al respecto puede verse NolL, G., «Seeking Asylum at Embassies: A Right to Entry under International Law?», International Journal of Refugee Law, vol. 15, 2005, pp. 542-557. 
derecho de asilo diplomático. En efecto, los tratados generales de derechos humanos presuponen que toda persona -incluidos los terroristas $\mathrm{u}$ otras personas acusadas de delitos graves- merecen protección y deberían poder invocar los derechos humanos ${ }^{104}$. Si bien en el marco de los tratados de derechos humanos, como el Convenio Europeo de Derechos Humanos y el Pacto Internacional de Derechos civiles y políticos, los deberes del Estado hacia personas que se encuentran fuera de su territorio no está del todo clara ${ }^{105}$, una de los pocas categorías sobre la que no existe controversia es la referida a las obligaciones de los Estados en materia de derechos humanos por parte de los funcionarios diplomáticos y consulares ${ }^{106}$. En ese sentido, de conformidad con lo establecido en la CEDH, se ha reconocido que el jefe de misión de un Estado Parte de dicha Convención también debe tener presente que existe la obligación para su Estado de no entregar a un refugiado a las autoridades locales en caso de que se considere que pueden llegar a infligirle tortura $\mathrm{u}$ otros tratos crueles, inhumanos o degradantes. Esta obligación se aplica a la conducta de los funcionarios diplomáticos o consulares del Estado acreditante, ya que ellos están bajo la jurisdicción y el control de dicho Estado ${ }^{107}$.

53. El Comité de Derechos Humanos (CDH) también ha aceptado que los actos de los funcionarios consulares pueden estar comprendidos en el ámbito del Pacto de Derechos Civiles y Políticos ${ }^{108}$. Por su parte, cabe recordar que, en su opinión consultiva sobre las Consecuencias jurídicas de la construcción de un muro en el territorio palestino ocupado, la CIJ consideró «que el Pacto de Derechos Civiles y Políticos es aplicable con respecto a los actos de un Estado en el ejercicio de su jurisdicción fuera de su propio territorio» ${ }^{109}$.

54. La opción de foro realizada por Ecuador no parece que vaya a tener efectos prácticos para la solución del caso. Quizás, como manifestara en su momento el Presidente Correa ${ }^{110}$, hubiese sido conveniente recurrir a la CIJ. Sin embargo, se trata de una alternativa menos amigable para Ecuador y cuya decisión resulta mucho más difícil de predecir. Si bien las opiniones consultivas de la Corte IDH gozan de alto prestigio, constituyen un referente normativo y han suscitado e impulsado cambios significativos tanto dentro

104 Véase, por ejemplo, Saadi v. Italy (GS), núm. 37201/06, TEDH 2008.

105 Milanovic, M., Extraterritorial Application of Human Rights Treaties, Oxford, University Press, 2011.

106 Al-Skeini y otros c. Reino Unido (GS), núm. 55721/07, párr. 134, TEDH 2011.

107 Véase el asunto B v Secretary of State for Foreign and Commonwealth Affairs (2004) EWCA 1344, Case Núm: C4/2004/0814 PTA, 18 de octubre de 2004, párr. 79.

108 Véase Vidal Martins v. Uruguay, núm. 57/1979, Doc. CCPR/C/15/D/57/1979 (1982), párr. 157; Lichtenstein v. Uruguay, núm. 77/1980, Doc. CCPR/C/OP/2 (1990), párr. 102; Montero v. Uruguay, núm. 106/1981, UN Doc. CCPR/C/OP/2 (1990), párr. 136; Núñez v. Uruguay, núm. 108/1981, Doc. CCPR/C/OP/2 (1990), párr. 143.

109 CIJ, opinión consultiva en el asunto Consecuencias jurídicas de la construcción de un muro en el territorio palestino ocupado, 9 de julio de 2004, párr. 111. Asimismo, puede verse LANGFORD, M. et al., Global justice, state duties: the extraterritorial scope of economic, social and cultural rights in international law, Cambridge, Cambridge University Press, 2013; DA CosTA, K., The Extraterritorial Application of Selected Human Rights Treaties, Leiden, Martinus Nijhoff Publishers, 2012.

110 «An Ecuadorean History of the World», The Economist, 25 de agosto de 2012. 
del sistema como fuera de él, la indeterminación de sus efectos así como su carácter no vinculante le restan fuerza normativa, más aún para aquellos sujetos que se encuentran fuera del sistema y no están obligados por sus normas ${ }^{111}$.

55. Las preocupaciones de Assange se refieren principalmente a su temor de ser extraditado por Suecia a los Estados Unidos por cargos de espionaje en relación con su papel, como fundador de WikiLeaks, en la divulgación al público de materiales confidenciales del gobierno estadounidense. Esa inquietud cobra mayor relevancia a tenor de las recientes declaraciones del Fiscal General de los Estados Unidos, Jeff Sessions, quien manifestó que el arresto de Julian Assange es una prioridad para su Gobierno y que el Departamento de Justicia va a intensificar sus esfuerzos para procesar al fundador de WikiLeaks ${ }^{112}$. Casi cinco años después de la concesión de asilo diplomático, las partes involucradas no han logrado encontrar una solución efectiva al caso, por lo que Assange continúa asilado en la Embajada ecuatoriana en Londres.

\section{EL FUTURO DEL ASILO DIPLOMÁTICO}

56. Las personas que sufren persecución han buscado refugio en las misiones diplomáticas durante siglos, pero esta práctica ha sido siempre y continúa siendo controversial. Al proporcionar protección de las autoridades del Estado territorial (receptor), el Estado asilante (acreditante) se involucra en cierta medida en asuntos internos de ese otro Estado. Ello produce un conflicto entre soberanos, entre sus opiniones y posiciones. A pesar de ello, por lo general, los Estados continúan brindando protección por razones humanitarias cuando creen que un individuo o un grupo de ellos es perseguido por razones políticas o enfrenta una amenaza inminente a su vida y/o su seguridad ${ }^{113}$.

57. El derecho a conceder asilo en las misiones diplomáticas a quienes son perseguidos por razones políticas por las autoridades del Estado receptor ha sido reivindicado con frecuencia, aunque no siempre ha sido aceptado y

111 No es este el espacio para profundizar en este tema, sobre el que existe abundante bibliografía. $\mathrm{Al}$ respecto pueden verse, entre otros, HitTERS, J. C., "¿Son vinculantes los pronunciamientos de la Comisión y de la Corte Interamericana de Derechos Humanos? (control de constitucionalidad y convencionalidad)», Revista Iberoamericana de Derecho Procesal Constitucional, vol. 10, 2008, pp. 131-156; SALVIOLI, F., "La competencia consultiva de la Corte Interamericana de Derechos Humanos: marco legal y desarrollo jurisprudencial», en VVAA, Homenaje y Reconocimiento a Antônio Cançado Trindade, Brasilia, Ed. Sergio Fabris, 2004, t. III, pp. 417-472; Wolfrum, R., «Las opiniones consultivas como un mecanismo para solucionar controversias internacionales», ESIL Newsletter, vol. 1, febrero de 2011, disponible en español en https://aquiescencia.net/2011/03/16/las-opiniones-consultivas-comoun-mecanismo-para-solucionar-controversias-internacionales-por-rudiger-wolfrum/ (consultada el 30 de abril de 2017).

112 SMITH, D., "Arresting Julian Assange is a priority, says US attorney general Jeff Sessions», The Guardian, 20 de abril de 2017.

113 VÄrk, R., «Diplomatic asylum: Theory, Practice and the Case of Julian Assange», 11 Sisekaitseakadeemia Toimetised, 2012, pp. 240-257, p. 240. 
aún no existe un acuerdo universal entre los Estados sobre las circunstancias en que puede ejercerse el derecho.

58. Si bien todos los Estados respetan la inviolabilidad de los locales de las misiones diplomáticas, ciertamente no existe una norma internacional que reconozca expresamente el asilo diplomático y que obligue a un Estado territorial a otorgar un salvoconducto a los asilados ${ }^{114}$. Entre los Estados latinoamericanos se ha aceptado un derecho de asilo diplomático, habiéndose celebrado acuerdos internacionales entre estos países que establecen reglas para el ejercicio del derecho.

59. De conformidad con el Derecho internacional general vigente, el asilo diplomático es una cuestión de práctica humanitaria más que un derecho, por lo que se acepta que puede concederse únicamente con el fin de salvar vidas o prevenir daños ante una amenaza inmediata al asilado. Aún en este supuesto, se sostiene que, en ausencia de una costumbre o uso local reconocido, la protección debería concederse solo de manera temporal y el fugitivo debería ser entregado ante una demanda de las autoridades locales, a menos que se acuerde un salvoconducto para asegurar su salida del Estado receptor ${ }^{115}$.

60. Como lo expresara la CIJ en el asunto Haya de la Torre:

«La decisión de conceder asilo diplomático supone una derogación de la soberanía del Estado; sustrae al delincuente de la justicia del último y constituye una intervención en ámbito que depende exclusivamente de la competencia del Estado territorial. Dicha excepción a la soberanía territorial no puede reconocerse a menos que se establezca su base jurídica en cada caso particular» ${ }^{116}$.

61. Los intentos internacionales recientes para lograr una aceptación formal universal del derecho de asilo diplomático, como los cumplidos por el Instituto de Derecho Internacional en 1950 y en la Asamblea General de las Naciones Unidas, no han tenido éxito.

62. El derecho de asilo diplomático es una institución que ha vivido y vive entre dos fuerzas que en ocasiones actúan en una dirección convergente y, por lo general, en un sentido discordante. De un lado, aparece el principio de la soberanía estatal y del otro, el derecho humano a buscar protección por parte de quien es perseguido por motivos políticos. Hasta el momento, los Estados en ejercicio de su soberanía, con excepción de los latinoamericanos, han impedido o no han podido consensuar un instrumento internacional, que establezca el derecho de asilo diplomático de quienes huyen de la persecución política.

63. El sentido de los conceptos e instituciones jurídicas internacionales depende del contexto en el que se invocan, a menudo en yuxtaposición polémica a posiciones o puntos de vista contrastantes. Para comprender cabalmente su significado, debemos saber qué política se pretende apoyar, o contra quién o qué tipo de preferencia se espera que funcione. Los concep-

114 Bederman, D. J., The Spirit of International Law, Georgia, University of Georgia Press, 2002, p. 73.

115 Roberts, I., Satow's Guide to Diplomatic Practice, 6. . ed., Oxford, Oxford University Press, 2009 , párr. 8.24 , p. 110 .

116 CIJ, «Derecho de asilo (Colombia c. Perú)»(1950), del 20 de noviembre de 1950, pp. 274-275. 
tos e instituciones jurídicas internacionales son en este sentido intensamente contextuales ${ }^{117}$. Por ello, el asilo diplomático no puede concebirse exclusivamente como un problema de naturaleza inequívocamente jurídica, sino que es a la vez un problema político. Consecuentemente, al considerar el caso de Assange, el análisis no puede centrarse exclusivamente en el marco jurídico sino en su intersección entre la soberanía del Estado, la política exterior, la diplomacia y las exigencias que plantean las relaciones internacionales contemporáneas, lo que excede largamente el objetivo de este trabajo.

64. Si bien el asilo diplomático puede ser percibido como una práctica que, en términos estrictamente legales, no responde a una norma de Derecho internacional; sus ramificaciones pueden ser de tal importancia que es una institución que continúa siendo utilizada incluso por aquellos países que más lo desaprueban. En el caso Assange se enfrentan no solo los Estados directamente involucrados, es decir, Ecuador de una parte y el Reino Unido, Suecia y Estados Unidos por otra, sino que se produce un conflicto de regímenes jurídicos entre quienes reconocen el derecho al asilo diplomático (América Latina) y los que no lo hacen. El Derecho internacional, y el diplomático en particular, no tienen una solución clara para este tipo de situaciones, lo que genera una indeterminación normativa y factual. Aún en el ámbito latinoamericano, el contenido del derecho de asilo no es lo suficientemente claro, donde se mezcla la institución del asilo político, el diplomático y la del refugio, como se desprende la solicitud de opinión consultiva de Ecuador a la Corte IDH. Ciertamente la opinión de este tribunal contribuirá a aportar cierta claridad, al menos en el plano regional. Sin embargo, cualquiera que sea la opinión de la Corte IDH, se enfrentará con la abierta oposición de quienes desconocen la institución del asilo diplomático.

65. A mi juicio, resulta dudoso que Assange estuviera realmente en una situación tan aguda de angustia que justificara el otorgamiento de asilo diplomático, aún con los requisitos y condiciones con que es aceptado en América Latina y tal como fue interpretado por la CIJ en el caso Haya de la Torre. Una medida extrema para terminar con el asilo diplomático sería la decisión del Estado receptor de considerar que el asilo constituye un abuso de los privilegios e inmunidades que goza el Estado acreditante y poner fin a las relaciones diplomáticas entre los dos Estados, instruyendo el cierre de la misión del Estado acreditante. El Reino Unido no parece dispuesto a llegar a este extremo en el caso Assange. Tampoco pareciera estar dispuesto a ingresar a la Embajada ecuatoriana en Londres para detener a Assange, aun cuando en el plano interno la Diplomatic and Consular Premises Act de 1987 lo habilitaría a ello.

66. La opción de foro realizada por Ecuador procura que el derecho de asilo diplomático salga reforzado. Ello no obstante, desde un punto de vista práctico, carecerá de efectos para solucionar una situación en la que los regímenes jurídicos latinoamericano y europeo aparecen enfrentados. Aunque

117 Crawford, J. y Koskenniemi, M. (eds.), The Cambridge Companion to International Law, Cambridge, Cambridge University Press, 2012, p. 4. 
en el Derecho internacional general o en el Derecho internacional de los derechos humanos no parece existir una regla que permita fundamentar que Ecuador conceda asilo a Assange, el Reino Unido también carece de herramientas jurídicas que le permitan poner fin al asilo. El destino de Assange se asemeja al de una larga serie de precedentes históricos, como el caso Haya de la Torre, en los que el asilo diplomático se transformó en estancias prolongadas. Aunque el resultado es insatisfactorio desde la perspectiva del Derecho internacional, el arduo equilibrio entre los principios de soberanía territorial e inviolabilidad diplomática genera incentivos para resolver las disputas por vía diplomática ${ }^{118}$. En este sentido, es de esperar que el asilo de Julian Assange en la Embajada de Ecuador, que ya lleva cinco años de duración, tiempo similar al que permaneciera Haya de la Torre en la Embajada de Colombia en Perú, pueda resolverse a través de una solución diplomática, que permita el otorgamiento de un salvoconducto para que Assange pueda salir del Reino Unido, como en el caso Haya de la Torre.

67. Finalmente, dado que la concesión del asilo diplomático representa una intervención considerable en los asuntos internos de un Estado, sería deseable que esta medida fuera objeto de algún tipo de regulación, inclusive aún para aquellos que se oponen al derecho de asilo diplomático, que buscan evitar abusos y consideran que debería otorgarse únicamente por razones humanitarias. Para ello podrían retomarse los antecedentes de 1975 y lo ocurrido desde entonces en materia de derechos humanos y de los refugiados. Una vía alternativa para sustentar la legalidad del asilo diplomático podría ser adaptar el principio de no intervención a las obligaciones específicas en materia de derechos humanos ${ }^{119}$. Como lo señaló la jurisprudencia británica, el Estado acreditante podría llegar a violar esas obligaciones en el caso de que un individuo le solicite protección en el Estado receptor ${ }^{120}$. En teoría, las obligaciones de los derechos humanos del Estado acreditante se podrían complementar con las obligaciones que debe al Estado receptor ${ }^{121}$.

68. Sin embargo, un proceso de codificación del asilo diplomático no está a la vista. Quizás, el caso Assange contribuya a que los Estados se sienten nuevamente a discutir esta acuciante cuestión.

\section{RESUMEN}

\section{WIKILEAKS, ASSANGE Y EL FUTURO DEL ASILO DIPLOMÁTICO}

Este artículo considera la terminología, el marco jurídico y la práctica del asilo diplomático, para después referirnos en concreto a la situación de Julian Assange, incluyendo la

\footnotetext{
118 En el mismo sentido, Roldán BARBero, J., "Assange, entre la política y el derecho», El País, 22 de agosto de 2012.

119 ARREDONDO, R., Intervención humanitaria y responsabilidad de proteger: ¿hacia un nuevo paradigma de protección de los derechos humanos?, Buenos Aires, Catálogos, 2012.

120 Véase punto 2.4 supra.

121 Den HeIJer, op. cit., nota 28, pp. 411-412.
} 
reciente solicitud de una opinión consultiva de Ecuador a la Corte Interamericana de Derechos Humanos. Concluye con algunas reflexiones acerca del futuro del asilo diplomático.

Palabras clave: asilo diplomático, derechos humanos, refugiados, derecho diplomático y consular, inviolabilidad, Assange, América Latina, CDH, Corte IDH, TEDH.

\section{ABSTRACT}

\section{WIKILEAKS, ASSANGE AND THE FUTURE OF DIPLOMATIC ASYLUM}

The article first studies the terminology and forms of asylum, then examines the legality of diplomatic asylum under international law and state practice of providing diplomatic asylum and analyses the case of Julian Assange, including the request of an advisory opinion made by Ecuador to the Inter-American Court of Human Rights. Finally, some conclusions are drawn on the future of the practice of diplomatic asylum.

Keywords: diplomatic asylum, human rights, refugees, diplomatic and consular law, inviolability, Assange, Latin America, HRC, ICHR, ECHR. 